\title{
The Anxiety In Facing Retirement For Indonesian National Army Soldiers
}

\author{
Agustin Handayani ${ }^{*}$, Joko Kuncoro \\ The Faculty of Psychology, Unissula Semarang, Jl Kaligawe Raya Km .4, Terboyo Kulon, Kec Genuk, 5022, Kota Semarang, Jawa Tengah, Indonesia \\ *Corresponding author: agustin@unissula.ac.id
}

Article history: Received: 11 January 2020 Received in revised form: 28 June 2020 Accepted: 10 May 2021 Published online: 09 August 2021

\begin{abstract}
The aim of this research is to discover the correlation between anxiety level of retirement and self-adaptation, social support, years of service and age on Indonesian National Army Soldiers at Kodim (Military District Command). This research used a quantitative research method carried out on 97 soldiers at Kodim. The sampling method used cluster random sampling. This research used three measurement scales. The anxiety of retirement scale consisted of 23 items with the coefficient correlation starts from $0.377-0.653$ and a reliability coefficient of 0.723 . The social support scale consisted of 29 items with a coefficient correlation starts from $0.369-0.775$ and a reliability coefficient of 0.936 . The self-adjustment scale consisted of 40 items with a coefficient correlation starts from $0.325-0.249$ and a reliability coefficient of 0.959 . There are five models to be analyzed in this study, using regression analysis of two predictors and partial correlation with the assistance of SPSS version 19.0. The results of the analysis of the model 1 (social support, adjustment and anxiety), model 2 (social support, adjustment, word period and anxiety), model 3 (social support, adjustment, age and anxiety) and model 4 (social support, adjustment, age, years of service and anxiety) show a significant correlation between all variables tested. Hypothesis 1 to 4 are accepted. Meanwhile, the result of the hypothesis model 5 (years of service, age and anxiety) shows that there is no correlation between all variables tested. Fifth hypothesis is rejected.
\end{abstract}

Keywords: The Anxiety of Retirement, Social Support, Self-Adjustment, Years of Service, Age.

(C) 2021 Penerbit UTM Press. All rights reserved

\subsection{INTRODUCTION}

To work is an absolute necessity and must be done by every human being. To work, besides as a means to get a source of income, it also becomes a symbol of self-identity (Fuaddi, 2018). An individual who has an identity means he is recognized by others and society as a person who has a clear meaning and role in society. Schiamberg and Smith (1981) suggested that by working individual needs for appreciation and competence can be met. However, this pleasure becomes reduced when the person enters retirement (Hurlock, 1996).

Like Civil servants, the deployment of soldiers is also limited by time. This means that when the working period limit is determined, the soldier must quit or retire. The Maximum retirement age limit for the Dismissal of the National Police is fifty-eight (58) years and it is applied to all ranks of the National Police. According to Law No. 34 of 2004 concerning the Indonesian National Army Article 53 on welfare, it was said that soldiers carrying out military services have a maximum age of fifty-eight (58) years. Retirement is a partial or complete withdrawal from work accompanied by a decrease in income (Fadila \& Alam, 2016). Retirement is a stage of separation as well as the final stage of the cycle of the Army personnel development system, which is given by the government as a form of appreciation for military members for the future after he is officially discharged respectfully from military service, as explained in Indonesian Law No. 6 of 1966 concerning Provision, Benefits, and Voluntary Allowances for the retirement.

Retirement is a loss process that requires an adaptation process (Potter and Perry, 2008). Retirement is a period that is considered uncertain by some Indonesian National Army soldiers due to changes in activities undertaken daily such as every day leaving for work to become unemployed, from those who previously held a position suddenly have to stay at home, from always earn a high enough income to earn a lower living income, and of course loss of friendship with co-workers or reduced social contact. One disorder that often arises when individuals face retirement is anxiety (Nurhayati \& Indriyana, 2015). Anxiety is the emergence of negative emotions that are characterized by a sense of worry, sadness and fear at different levels between one individual with another individual (Atkinson, 1990). The fear that arises when entering retirement is felt differently in each individual, it occurs because of the inability of individuals to deal with various life uncertainties in the future (Sutrisno, 2013).

One of the causes of anxiety in facing retirement is self-adjustment. Hurlock (1996) argued that the inability to make adjustments can be a factor in the emergence of anxiety when facing retirement because when entering retirement, a person will also face social change. Individuals with good adaptability when retirement comes will usually do better preparation and planning so that individuals are able to reduce and even overcome concerns that are felt so that when retirement comes such individuals will not feel worried, afraid, even confused about what activities to do. Conversely, if individuals are realistic and objective when entering retirement and do not consider retirement to be a frightening period, they need to be worried. They will have negative thoughts about retirement and it is not surprising that individuals are able to prevent anxiety from arising when they will retire (Pradono \& Purnamasari, 2010). 
A good adjustment for individuals who will retire is inseparable from social support, especially from relatives and closest people. In this case, the family has an important role in the life of the individual. However, the lack of social support from the environment and family can affect the level of anxiety of individuals in facing retirement. Social support is an important aspect for individuals to make the necessary changes in dealing with new roles (Ikawati \& Gutomo, 2014). Pradono and Purnamasari (2010) said that anxiety in facing retirement is a condition that is certainly not pleasant and is very subjective. Ghufron and Risnawita (2010) explain several factors that cause anxiety to arise, namely internal factors such as religiosity, fear of failure, pessimism and external factors such as lack of social support, and low attention from the environment. Hurlock (1996) adds that self-adjustment is also an aspect that affects individual anxiety (Pradono \& Purnamasari, 2010)

Lazarus (Pradono \& Purnamasari, 2010) defined adjustment as a psychological process carried out by individuals to overcome or face various demands or pressures. Dymon (Putri, 2010) revealed that if an individual has a positive adjustment, it will be manifested in an optimistic, flexible and emotional maturity. Sarafino (in Smet, 1994) stated that social support is when individuals can feel pleasure, attention, affection and feelings of being loved so that they can have value and prestige in the group. Social support received will have a more psychologically and physically healthier effect than individuals who reject the presence of social support.

Larocco (Toifur, 2003) stated that the assistance behavior obtained from interpersonal relationships is interpreted as social support, even the existence of good social support can be used as a coping tool to deal with stressful situations. This can happen because social support can form a balance in both mental and psychological satisfaction. Based on the explanation in the background above, the researcher formulated the problem as follows:

1) Is there any correlation between self-adjustment and social support with the anxiety in facing retirement on Indonesian National Army soldiers.

2) Is there any correlation between adjustment, social support and years of service with the anxiety in facing retirement on Indonesian National Army soldiers?

3) Is there any correlation between self-adjustment, social support and age with the anxiety in facing retirement on Indonesian National Army soldiers?

4) Is there any correlation between adjustment, social support, years of service and age with anxiety in facing retirement on Indonesian National Army soldiers?

5) Is there any correlation between years of service and age with anxiety in facing retirement on Indonesian National Army soldiers?

\subsection{METHODOLOGY}

The population in this study were Indonesian National Army soldiers serving at Kodim (Military District Command) 0716/Demak. The total number of subjects of the study were 95 soldiers in Koramil (military rayon command) 1/Demak city, Koramil 2 / Bonang, Koramil 7/Gajah, Koramil 8/ Karanganyar, Koramil 9/Karang Tengah, Koramil 13 / Karangawen, and Kodim 0716/ Demak. The sampling technique in this study was a cluster random sampling. The sampling technique was done by taking subjects based on certain regional clusters that exist in the population.Data collection methods used in this study were using the scale. The scale used in this study is the scale of the anxiety infacing retirement, social support and adjustment. The analysis technique in this study used the four-predictor regression analysis technique. Regression was carried out using five models to determine the effect of each predictor on the criteria. The analysis technique in this study used the four-predictor regression analysis technique. Regression was carried out using five models to determine the effect of each predictor on the criteria.

\subsection{RESULTS}

Based on the results of the analysis using SPSS (Statistical Product and Service Solution), the following research results are obtained:

\section{a. Model 1}

Model 1 is the initial model that examines the correlation between self-adjustment and social support and anxiety of retirement towards Indonesian National Army soldiers at Kodim 0716. The correlation test results obtained the score of $R=0.712$ and Fcount $=47.396$ with a significance level of 0.000 ( $\mathrm{p}<0.05$ ). These results indicate that there is a significant correlation between adjustment and social support with anxiety facing retirement at soldiers of the Kodim 0716 / Demak. Therefore, it is concluded that the first hypothesis is accepted.

Based on the calculation results in Table 1, it was also obtained that an overall effective contribution (SE) is $50.7 \%$ or equal to the coefficient of determination of the results of $\mathrm{R}$ square regression analysis of 0.507 . This shows that the variable of social support and adjustment respectively contribute $50.7 \%$ on the effectiveness of anxiety in facing retirement variables.

Table 1 Correlation between self-adjustment, social support, and anxiety

\begin{tabular}{|c|c|c|c|c|c|c|c|}
\hline \multirow[b]{2}{*}{ Model } & \multirow[b]{2}{*}{$\mathrm{R}$} & \multirow[b]{2}{*}{ R Square } & \multirow[b]{2}{*}{ Adjusted R Square } & \multirow[b]{2}{*}{ Std. Error of the Estimate } & \multicolumn{3}{|c|}{ Change Statistics } \\
\hline & & & & & R Square Change & F Change df1 df2 & Sig. F Change \\
\hline 1 & $.712^{\mathrm{a}}$ & .507 & .497 & 3.090 & .507 & $2 \quad 92$ & .000 \\
\hline
\end{tabular}


b. Model 2

The correlation test in this study with model 2 used a three-predictor regression analysis by entering the service life variable into the initial model. This model aims to test whether there is a correlation between adjustment, social support and year of service with the anxiety in facing retirement at Indonesian National Army soldiers at Kodim 0716. The results of the correlation test conducted obtained a score of $\mathrm{R}$ $=0.724$ and Fcount $=33.505$ with a significance level of $0.000(\mathrm{p}<0.05)$. These results indicate that there is a significant correlation between adjustment, social support and years of service with anxiety in facing retirement at soldiers of Kodim 0716 / Demak. Therefore, it is concluded that the second hypothesis is accepted.

Based on the calculation results shows in Table 2, it was also obtained an overall effective contribution (SE) is $52.5 \%$ or equal to the coefficient of determination of the results of $\mathrm{R}$ square regression analysis of 0.525 . This shows that the variables of adjustment, social support and years of service respectively contribute $52.5 \%$ to the effectiveness of the anxiety in facing retirement variable.

Table 2 Correlation between self-adjustment, social support, years of service, and anxiety

\begin{tabular}{|c|c|c|c|c|c|c|c|}
\hline \multirow[b]{2}{*}{ Model } & \multirow[b]{2}{*}{$\mathrm{R}$} & \multirow[b]{2}{*}{ R Square } & \multirow[b]{2}{*}{ Adjusted R Square } & \multirow[b]{2}{*}{ Std. Error of the Estimate } & \multicolumn{3}{|c|}{ Change Statistics } \\
\hline & & & & & R Square Change & F Change df1 df2 & Sig. F Change \\
\hline 1 & $.724^{\mathrm{a}}$ & .525 & .509 & 3.051 & .525 & 33.505 & .000 \\
\hline
\end{tabular}

\section{c. Model 3}

The correlation test on model 3 was done by adding the age variable to the initial model. The aim is to test whether there is a correlation between adjustment, social support and age with anxiety in facing retirement at Indonesian National Army soldiers at Kodim 0716 / Demak. The results of the correlation test conducted obtained a score of $\mathrm{R}=0.730$ and Fcount $=34.549$ with a significance level of 0,000 $(\mathrm{p}<0.05)$. These results indicate that there is a significant correlation between social support, adjustment and age with anxiety in facing retirement at soldiers of the Kodim 0716. It is concluded that the third hypothesis is accepted.

Based on the calculation results in Table 3, it was also obtained that an overall effective contribution (SE) is $53.2 \%$ or equal to the coefficient of determination of $\mathrm{R}$ square regression analysis results of 0.532 . This shows that the variables of social support, adjustment and age respectively contribute $53.2 \%$ to the effectiveness of the variable of anxiety in facing retirement.

Table 3 Correlation between self-adjustment, social support, age, and anxiety

\begin{tabular}{|c|c|c|c|c|c|c|c|}
\hline \multirow[b]{2}{*}{ Model } & \multirow[b]{2}{*}{$\mathrm{R}$} & \multirow[b]{2}{*}{ R Square } & \multirow[b]{2}{*}{ Adjusted R Square } & \multirow[b]{2}{*}{ Std. Error of the Estimate } & \multicolumn{3}{|c|}{ Change Statistics } \\
\hline & & & & & R Square Change & F Change df1 df2 & Sig. F Change \\
\hline 1 & $.730^{\mathrm{a}}$ & .532 & .517 & 3.026 & .532 & $\begin{array}{lll}34.549 & 3 & 91 \\
\end{array}$ & .000 \\
\hline
\end{tabular}

\section{d. Model 4}

The Correlation test in this study with model 4 used regression analysis of four predictors, i.e., by entering four independents' variables simultaneously. The aim is to test whether there is a correlation between adjustment, social support, years of service and age with anxiety in facing retirement on soldiers of the Kodim 0716 / Demak. The results of the correlation test conducted obtained a score of $\mathrm{R}=0.730$ and Fcount $=25.653$ with a significance level of $0.000(\mathrm{p}<0.05)$. These results indicate that there is a significant correlation between adjustment, social support, years of service and age with anxiety in facing retirement on soldiers of Kodim 0716 / Demak. It is concluded that the fourth hypothesis is accepted.

Based on the calculation results in Table 4, it was also obtained an overall effective contribution (SE) was $53.3 \%$ or equal to the coefficient of determination of the $\mathrm{R}$ square regression analysis results of 0.533 . This shows that the variables of adjustment, social support, years of service and age respectively contribute $53.3 \%$ on the effectiveness of the anxiety infacing retirementvariables.

Table 4 Correlation between self-adjustment, social support, years of service, age, and anxiety

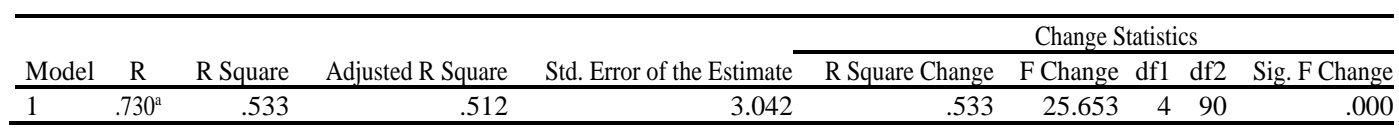

\section{e. Model 5}

The Correlation test in this study with model 5 used a two-predictor regression analysis which aims to test whether there is a correlation between years of service and age with anxiety in facing retirement in Indonesian National Army soldiers at Kodim 0716 / Demak. The correlation test results on Table 5 shown that the score of $\mathrm{R}=0.047$ and Fcount $=0.101$ with a significance level of 0.904 ( $p>0.05$ ). These results indicate that there is no significant correlation between years of service and age with anxiety in facing retirement on soldiers of the Kodim 0716 / Demak. In other words, years of service and age did not appear to be a cause of anxiety for Indonesian National Army soldiers at Kodim 0716 / Demak in facing retirement. It is concluded that the fifth hypothesis is rejected. 
Table 5 Correlation between age, years of service, and anxiety

\begin{tabular}{|c|c|c|c|c|c|c|c|c|}
\hline \multirow[b]{2}{*}{ Model } & \multirow[b]{2}{*}{$\mathrm{R}$} & \multirow[b]{2}{*}{ R Square } & \multirow[b]{2}{*}{ Adjusted R Square } & \multirow[b]{2}{*}{ Std. Error of the Estimate } & \multicolumn{4}{|c|}{ Change Statistics } \\
\hline & & & & & R Square Change & F Change & df1 df2 & Sig. F Change \\
\hline \multirow[t]{2}{*}{1} & $\mathrm{a}$ & & & & & & & \\
\hline & .047 & .002 & -.020 & 4.397 & .002 & .101 & 292 & .904 \\
\hline
\end{tabular}

Comparisons among analytical models can be seen more clearly in table 6 below:

Table 6 Comparison among model

\begin{tabular}{lccccc}
\hline \multicolumn{1}{c}{ Model } & $\mathrm{R}$ & $\mathrm{R}^{2}$ & $\mathrm{~F}$ & $\mathrm{p}$ & Des. \\
\hline Model 1 $\left(\mathrm{X}_{1}\right.$ dan $\left.\mathrm{X}_{2}\right) \rightarrow \mathrm{Y}$ & 0.712 & 0.504 & 47.369 & 0.000 & $\mathrm{~S}$ \\
\hline Model 2 $\left(\mathrm{X}_{1}, \mathrm{X}_{2,} \mathrm{X}_{3}\right) \rightarrow \mathrm{Y}$ & 0.724 & 0.525 & 33.505 & 0.000 & $\mathrm{~S}$ \\
\hline Model 3 $(\mathrm{X} 1, \mathrm{X} 2, \mathrm{X} 4) \rightarrow \mathrm{Y}$ & 0.730 & 0.532 & 34.549 & 0.000 & $\mathrm{~S}$ \\
\hline Model 4 $(\mathrm{X} 1, \mathrm{X} 2, \mathrm{X} 3, \mathrm{X} 4) \rightarrow \mathrm{Y}$ & 0.730 & 0.533 & 25.653 & 0.000 & $\mathrm{~S}$ \\
\hline Model 5 $\left(\mathrm{X}_{3}\right.$ dan $\left.\mathrm{X}_{4}\right) \rightarrow \mathrm{Y}$ & 0.047 & 0.002 & 0.101 & 0.904 & $\mathrm{NS}$ \\
\hline In which. X1: Self-Adjustment, X2: Social Support, X3: Years of Service; X4: Age, Y: Anxiety & &
\end{tabular}

\subsection{DISCUSSION AND RECOMMENDATION}

a. Model 1: There Is a Correlation Between Self-Adjustment and Social Support with Anxiety Facing in Retirement on Indonesian National Army Soldiers of Kodim 0716

From the results of testing the research data outlined above, it can be concluded that the first hypothesis is accepted that there was a significant correlation between social support and adjustment to the anxiety in facing retirement on Indonesian National Army soldiers at Kodim 0716.

Retirement is a period that comes based on achieving a certain age. Many people assume that retirement is a sign that someone is aging and cannot work productively anymore. For older people, retirement is a significant transition period that affects change (Seligman, 1980). When this happens, physiological changes cannot be avoided, and can also result in emotional changes. In Indonesia, the changes that occur when facing retirement are also experienced by civil servants. One case related to civil servants is reported that at least there are civil servants who have had strokes due to undergoing retirement. This is because they experience adjustment issues related to economic factors due to differences in income received while still working and retiring (Sopian, 2014).

The findings of this study reinforce the Atamimi's explanation (Pradono \& Purnamasari, 2010) which found that there are several factors that affect anxiety when facing retirement. These factors are divided into physical factors, social factors, economic factors, and psychological factors. Physical factors include reduced physical strength, health, and decreased memory. Social factors can be interpreted as the absence of social support from the surrounding environment so that it can make individuals feel useless. Economic factors can be in the form of decreased income which can create its own burden, causing anxiety. Psychological factors include feeling unappreciated and feeling underestimated due to deteriorating physical condition. In addition, Hurlock (1996) added that adjustment is also one of the factors that can affect the emergence of anxiety in facing retirement, because upon retirement the individual experiences a change in lifestyle so that good adjustment is needed.

Retirement can have positive and negative effects when viewed from someone's adjustment. Positive adjustment is determined by various factors including health, socio-economic, status, age, gender, and one's perception of retirement (Eliana, 2003). When someone can accept his situation well, then the retirement will be interpreted as a pleasant period. But the reality is that many people are not ready when facing retirement so that it can cause anxiety that leads to the post-retirement syndrome.

Soldiers with good adaptation will tend to do good preparation and planning, be able to understand and accept themselves by being realistic about the arrival of retirement. This enables them to reduce or overcome the worries that arise so that they no longer feel confused with the activities that will be done. Adjustment to Indonesian National Army soldiers of Kodim 0716 / Demak is inseparable from social support, especially from people in individual living environments.

Ikawati \& Gutomo (2014) argue that social support is an important aspect for individuals to make the necessary changes in dealing with new roles. Social support in the form of giving emotional support and acceptance can help adjustments in retirement and individuals get the feeling still useful, valuable, and happy (Birren \& Sloanne, 1980). However, the family is the most important thing among social supports, because the family is the environment that is closest to the individual. Isnawati and Suhariadi (2013) also said that social support from friends, family, and the surrounding environment can facilitate individuals in terms of adjusting to changes that occur during retirement.

b. Model 2: There Is a Correlation Between Self-Adjustment, Social Support and Work Period with Anxiety in Facing Retirement on Indonesian National Army at Kodim 0716.

From the results of testing the research data outlined above, it can be concluded that the second hypothesis is accepted that there was a significant correlation between adjustment, social support and work tenure with anxiety in facing retirement on Indonesian National Army soldiers at Kodim 0716. 
The results showed that the majority of respondents did not experience anxiety in facing retirement because retirement is one of the loss processes which requires an adaptation process (Potter and Perry, 2008). Moreover, in accordance with the results of the study, resulting in that the length of service affects one's readiness in facing the retirement process supported by good self-adjustment and family support does not make Indonesian National Army soldiers experience anxiety. This is in accordance with the Manpower Law in Article 50 of Law number 13 of 2003 which states that "Work relations occur because of an employment agreement between the employer and the worker/laborer. Furthermore, article 56 paragraph 1 also explained that "work agreements made for a certain period or for a period of time not specified". That way a negative view of retirement can be anticipated, especially for Indonesian National Army soldiers who have a relatively long period of service tend to be more ready to retire compared to those whose tenure has not been too long.

\section{c. Model 3: There Is a Correlation between Self-Adjustment, Social Support and Age with Anxiety in Facing Retirement on} Indonesian National Army Soldiers at Kodim 0716

From the results of testing the research data outlined above, it can be concluded that the third hypothesis is accepted that there was a significant correlation between adjustment, social support, and age with anxiety in facing retirement on Indonesian National Army soldiers at Kodim 0716.

Someone's retirement can generally feel calm because it has reached the peak point of his career at work. Individuals no longer bear the work responsibilities given by the agency or organization where they work, so that what is felt is a feeling of peace, calm, relief, relax and happiness.

In fact, many people are not quite ready to enter retirement. Retirement is considered as a rigid old age, unproductive, sick, dependent, poor and useless. This can directly cause psychological problems that cause anxiety because they do not know the picture of a life that will be faced later after retirement (Rini, 2001).

When someone is at the age of 55 years, in the task of development it means that he is still in the middle adulthood development. This is very different from Western countries that apply a retirement age at the age of 65 years and in the categorization of age according to Hurlock has entered late adulthood or middle adulthood (Hurlock, 1980). Age 55 years (middle adulthood) is generally considered to be a dangerous age in the life span because at that time the period in which a person experiences physical distress due to overwork, excessive anxiety or not paying attention to life. In fact, one of the tasks of development in middle adulthood is achieving and maintaining satisfying achievements in a career. It is certainly very likely to be absorbed because someone who can still have a career must be faced with a demand that is retirement.

Referring to one of the developmental tasks in late adulthood is adjusting to retirement and reducing family income (Hurlock, 1980). When associated with modern life like this, work is something that can not be separated from humans because the work can bring money, position, and self-esteem. Therefore, it often happens that people who retire instead of experiencing the pleasure of enjoying old age with a relaxed life but experience serious problems with their mental and physical. Considering that retirement age in Indonesia is still in its adulthood stage, which can be said to be psychologically productive, of course, the impact of this retirement process can cause more severe psychological effects (Eliana, 2003).

d. Model 4: There Is a Correlation Between Adjustment, Social Support, Work Period and Age with Anxiety Facing in Retirement on Indonesian National Army Soldiers at Kodim 0716

From the results of testing the research data outlined above, it can be concluded that the fourth hypothesis is accepted that there was a significant correlation between adjustment, social support, years of service, and age with anxiety in facing retirement on Indonesian National Military soldiers at Kodim 0716.

In general, the anxiety felt by someone who is about to retire is due to social change, such as anxiety about social identity, fear of alienation, anxiety due to unable to socialize more broadly, and the feeling of fear of losing co-workers (Fletcher \& Hansson, 1991).

Many cases occur that not everyone has a positive view of retirement because it occurs because of the unpreparedness of someone facing retirement. Research conducted by Holmes \& Rahe revealed that retirement occupies the top 10 for stress positions. By entering retirement someone will lose his social role in society, prestige, power, social contact, even self-esteem will also change due to loss of role. Many people before retirement have fallen ill and died because they are unable to face the fact that they will leave their jobs forever (Nabari, 2009). Even the worst effects on retirees can cause depression and suicide.

Every civil servant who is about to retire almost all suffer from adjustment problems due to valuable life changes and he has to adjust to new habits, but that depends on his individual personality or from the environment and his family. The characteristics of adjustment disorders are excessive anxiety because of the self-actualization feeling unappreciated after experiencing excessive anxiety because they can no longer meet the needs of the family (Kurniawan, 2012).

This is consistent with what was revealed by Kaplan \& Sadock (1997) that the factors associated with parental anxiety, namely internal and external factors, which age and years of service are one of the internal factors that contribute to the onset of anxiety in parents. Even some argue that the younger age factor is more prone to anxiety than old age but there are also those who argue otherwise.

\section{e. Model 5: There is a Correlation Between Years of Service and Age with Anxiety in Facing Retirement on Indonesian National Military Soldiers at Kodim 0716}

From the results of testing the research data outlined above, it can be concluded that the fifth hypothesis is rejected, that there was no significant correlation between tenure and age with anxiety in facing retirement on Indonesian National Army soldiers at Kodim 0716.

Old age is the final stage of life in the life cycle of humans and has been aged 60 years and over (Law No. 13 of 1998). Among civil servants and in BUMN/BUMD institutions, they will retire after reaching the age of 56 years (PP No 32 of 1979), except for teachers who can retire at 60 years old (PP Number 65 of 2008). PP No. 1 of 2003 Article 3 on Rules for Dismissal of the National Police states that the maximum retirement age limit of fifty-eight (58) applies to all ranks of the Indonesian National Police and RI Law No. 34 of 2004 
concerning the Indonesian National Army Article 53 on welfare says soldiers can carry out military service to the highest age of five twenty-eight (58) years.

Retirement is a loss process that requires an adaptation process (Potter and Perry, 2008). The results showed that the majority of respondents did not experience anxiety in facing retirement, although there were also those who experienced mild, moderate and severe anxiety with a smaller proportion than those without anxiety.

The results of this study are in line with research conducted by Sasongko, C. P \&Nurtjahjanti, H (2017) who stated that the majority of employees at PLN (Persero) Ltd. Semarang region has anxiety facing retirement in the low category, which reached to $70.67 \%$ of employees. This indicates that they have financial well being and follow the retirement preparation period well. PLN (Persero) Ltd. Semarang Region provides education and training in providing retirement period to provide supplies to employees who are about to retire in the form of certain skills as provisions for retirement. Wood (2012) stated that employees who follow retirement preparation periods do not feel afraid of losing productivity, while employees who do not follow retirement preparation periods will worry about losing productivity.

The level of well-being determines the individual in having a pleasant picture of retirement before it becomes a bad reality. The more people feel welfare, the picture of retirement will be brighter and more sustainable. Conversely, if they feel less prosperity, the faster the picture of retirement will fade into anxiety.

If someone is able to gradually withdraw from his job role, look for replacement activities, maintain the sustainability of activities in his new life and be able to actualize what new roles, he will assume then he will avoid psychological problems such as anxiety.

\subsection{CONCLUSION}

For employees who are about to retire, they should be able to prepare themselves well in advance so that when they approach and retire, they can adjust themselves both physically and psychologically so as to avoid a variety of psychological disorders such as anxiety, post power syndrome, and others. Preparations made before retirement should not only prepare in economic terms (financial) solely, but also mental preparation, social relations, and how to fill in the blanks from monotonous activities or can find other activities that can be done to fill the time during retirement later and others so. This should be discussed together with the closest people or family who are the main source in providing excellent social support so that entering a full time of duty or retirement can be led to live happily with the loved ones.

\section{References}

Atkinson, L.R., Atkinson, C.R., Smith, E.E., \& Bem, D. J. (1990). Pengantar Psikologi Edisi Kedelapan Jilid Dua. Jakarta: Erlangga

Birren, J. E., \& Sloanne, R. B. (1980). Handbook of Mental Health and Aging. New York: Prentice Hall Inc.

Eliana, R. (2003). Konsep Diri Pensiunan. (Master Thesis, University of Sumatera Utara, Medan). Retrieved from: www.library.USU.ac.id Retrieved on 08 January 2020 .

Fletcher, W.L. \& Hansson, O.R. (1991). Assesing the Social Componen Tretirement of Anxiety Scale. Psychology and Aging, 6(1),76-85. doi: $10.1037 / / 0882-7974.6 .1 .76$

Fuaddi, Husni. 2018. Etos Kerja dalam Perspektif Islam. Jurnal Al-Amwal, 7(1), 20 -31.

Ghufron, M. N., \& Risnawita, R. S. (2010). Teori-teori psikologi. Yogyakarta: Ar-Ruzz Media.

Hurlock, ElizabethB. (1980). Psikologi Perkembangan: Suatu Pendekatan Sepanjang Rentang Kehidupan. Jakarta: Erlangga

Ikawati, \& Gutomo, T. (2014). Pengaruh Dukungan Sosial Terhadap Kondis Kecemasan Dalam Menghadapi Pensiun. Jurnal PKS, 13(1), 83-98.

Isnawati, D. \& Suhariadi, D.H. (2013). Hubungan Dukungan Sosial dengan Penyesuaian Diri Masa Persiapan Pensiun pada Karyawan PT. Pupuk Kaltim. Jurnal Psikologi Industri dan Organisasi, 02(1), 1-6.

Kaplan, H. I. \& Sadock, B. J. (1997). Sinopsis Psikiatri (Synopsis of Psychiatry) diterjemahkan oleh Widjaya Kusuma. Jakarta: Bina Aksara

Kurniawan,F.A. (2012, May 23). Jelang Pensiun, Rata-rata 3 PNS Perhari ke Poli Jiwa. Surabaya Post Online. Retrieved 15 from http://www.surabayapost.co.id. Retrieved on 07 January 2020.

Nabari, T. (2009). Happy and Healthy Retiree. Yogyakarta: Andi.

Nurhayati, Istiqamah \& Indriana, Yeniar. 2015. Harga Diri dan Kecenderungan Post Power Syndrome pada Pensiunan Pegawai Negeri Sipil Anggota Pwri Cabang Kota Cirebon. Jurnal Empati, 4(1): 94-99.

Potter,P.A. \& Perry, A.G. (2008). Buku Ajar Fundamental Keperawatan: Konsep, Proses dan Praktek (Ed. 4). Jakarta: EGC.

Pradono, G. S., \& Purnamasari, S. E. (2010). Hubungan antara Penyesuaian Diri Dengan Kecemasan Dalam Menghadapi Masa Pensiun Pada Pegawai Negeri Sipil di Propinsi Daerah Istimewa Yogyakarta. Naskah Publikasi: Universitas Mercu Buana Yogyakarta.

Putri, S.A.P. (2010). Penyesuaian Diri pada Remaja Obesitas Ditinjau dari Kematangan Emosi dan Jenis Kelamin. Majalah Ilmiah Informatika, 1, 92-104.

Sasongko, C. P. \& Nurtjahjanti, H. (2017). Hubungan antara Self Disclosure dengan Kecemasan Menghadapi Pensiun Pada Pegawai PT. PLN (PERSERO) Wilayah Semarang. Jurnal Empati, 6(1), 54-60.

Schiamberg, L.B. \& Smith, K.W. (1981). Human Develepment. NewYork: Mc-Mi- llanPublishing Co.inc.

Seligman, L. (1980). Developmental Career Counseling and Assessment (2 ${ }^{\text {nd }}$ ed.). London: SAGE.

Smet, B. (1994). Psikologi Kesehatan. Jakarta: PT Grasindo.

Sopian, S. (2014). Dikabarkan Stroke, Waryono Berliburke Raja Ampat. Diperoleh April 24, 2017, from http;//hutte- stijl.com/2014/01dikabarkan-stroke-waryonoberlibur- ke.html?m=1

Sutrisno, E. (2013). Kematangan Emosional, Percaya Diri dan Kecemasan Pegawai Menghadapi Masa Pensiun. Jurnal Psikologi Indonesia, 2 (1), 1-11.

Rini, J.C. (2001). Pensiun dan Pengaruhnya. Retrieved September 29, 2012, from www.Psikologi/usia/person/com/htm:62k

Toifur. (2003). Hubungan antara Status Sosial Ekonomi Orientasi Religius dan Dukungan Sosial dengan Burnout pada Guru Sekolah Dasar di Kabupaten Cilacap. Jurnal Sosiohumanika, 16(3), 511-527.

Wood,G. (2012). Retiringmen: Manhood,labor, and Growing Old in America. Lanham:University Press of America. 